\title{
Web-Lembar Kerja Peserta Didik IPA terintegrasi potensi lokal pabrik gula untuk meningkatkan rasa ingin tahu peserta didik
}

\author{
Maulidiyani Fuadati *, Insih Wilujeng \\ Program Studi Pendidikan Sains, Program Pascasarjan, Universitas Negeri Yogyakarta. \\ Jalan Colombo No. 1, Karangmalang, Yogyakarta 55281, Indonesia. \\ * Coressponding Author. E-mail: diya.fuadatii@gmail.com \\ Received: 22 April 2019; Revised: 3 May 2019; Accepted: 20 May 2019
}

\begin{abstract}
Abstrak
Penelitian ini bertujuan untuk mengetahui kelayakan dan keefektifan web-Lembar Kerja Peserta Didik (LKPD) IPA terintegrasi potensi lokal pabrik gula. Penelitian ini merupakan penelitian pengembangan menggunakan model pengembangan 4D dengan tahap define, design, develop, dan disseminate. Penelitian ini menggunakan pretest posttest control group design. Penilaian kelayakan web-LKPD IPA dilakukan oleh ahli materi dan ahli media untuk mengetahui kelayakan produk, penilaian kepraktisan oleh guru IPA, serta respon peserta didik untuk mengetahui keterbacaan produk. Hasil penilaian kelayakan oleh ahli materi, media, guru IPA memperoleh skor sebesar 62, 38, dan 56 terhadap skor maksimal masing-masing sebesar 48,35 , dan 45 sehingga tergolong pada kategori sangat baik. Uji keterbacaan memperoleh persentase sebesar $93 \%$ respon positif dari peserta didik. Hasil skor gain ternormalisasi mendapat skor sebesar 0.36 pada kelas eksperimen dan tergolong pada kategori sedang dan terdapat peningkatan dalam pembelajaran. Efektivitas pembelajaran dilakukan dengan uji independent sample t test dengan nilai sig. sebesar 0.000 ( $\geq 0.05)$. Hasil penelitian menunjukkan bahwa pembelajaran dengan web-LKPD IPA terintegrasi potensi lokal efektif (sig. $0.00<0.05)$ meningkatkan rasa ingin tahu peserta didik SMP Negeri 1 Jombang.
\end{abstract}

Kata Kunci: web-LKPD IPA, potensi lokal, rasa ingin tahu

\section{Integrated worksheet web of nature history students on the local potentials of "Pabrik Gula" for increasing the students' curiosity}

\begin{abstract}
This study aims to determine the feasibility and effectiveness of the science web student worksheet integrated local potency "pabrik gula". This research is a development research using the 4D development model with the stages of define, design, develop, and disseminate. Assessment of the feasibility of science web student worksheet is carried out by material expert and media expert, the assessment by science teachers, and the responses of students to know the readability of the product. The results of the feasibility assessment by material, media expert, and science teachers scored 62, 38, and 56 for a maximum score of 48, 35, and 45 which were categorized as very good. Readability test obtained a percentage of $93 \%$ positive response from students. The normalized gain score results in a score of 0.36 in the experimental class and belongs to the medium category and there is an increase in learning. The effectiveness of learning is done by testing the independent sample t test with the sig .value amounting to 0.00 (more than 0.05). The results showed that learning with science web student worksheet integrated with local potency effective to enhance curiosity of Jombang Middle School 1 students.
\end{abstract}

Keywords: science web student worksheet, local potency, curiosity

How to Cite: Fuadati, M., \& Wilujeng, I. (2019). Web-Lembar Kerja Peserta Didik IPA terintegrasi potensi lokal pabrik gula untuk meningkatkan rasa ingin tahu peserta didik. Jurnal Inovasi Pendidikan IPA, 5(1), 98-108. doi:https://doi.org/10.21831/jipi.v5i1.24543

https://doi.org/10.21831/jipi.v5i1.24543

\section{PENDAHULUAN}

Proses pembelajaran IPA melibatkan berbagai aktivitas antara guru dan peserta didik dalam mendapatkan pengetahuan, membentuk sikap ilmiah maupun mengembangkan keterampilan sebagai aspek penting dalam kecakapan hidup. Salah satu sikap ilmiah yang penting untuk dikembangkan dalam Kurikulum 2013 yaitu rasa ingin tahu (Fithriyyati \& Maryani, 2018). Ketika 
peserta didik memiliki rasa ingin tahu yang tinggi, mereka berusaha untuk memahami, mengeksplorasi, serta menganalisis berbagai fenomena, gejala, dan peristiwa alam termasuk fenomena alam di sekitarnya. Hal itu dapat membantu peserta didik untuk mengasah pemahaman, menghubungkan informasi lama dan baru diperoleh, serta melatih berpikir kritis.

Proses pembelajaran IPA hanya berpusat pada pengembangan kognitif, tanpa melibatkan pengembangan aspek afektif seperti sikap, motivasi, dan moral (Dwianto, Wilujeng, Prasetyo, \& Suryadarma, 2017). Proses pembelajaran IPA dengan kondisi yang menarik dan menyenangkan dapat menumbuhkan motivasi belajar dan keingintahuan peserta didik. Berdasarkan hasil observasi di SMP Negeri 1 Jombang, ketika proses pembelajaran berlangsung, hanya sedikit peserta didik yang mengajukan pertanyaan maupun memberi tanggapan dalam proses diskusi. Selain itu peserta didik enggan dalam mengajukan pertanyaan ketika tidak memahami materi pembelajaran. Hal tersebut mengindikasikan kurangnya rasa ingin tahu dalam diri peserta didik.

Menurut Erdogan (2017) kurangnya rasa ingin tahu disebabkan oleh kegiatan diskusi dan tanya jawab antara guru dan peserta didik yang pasif, guru biasanya memberi pertanyaan atau masalah dengan tingkat kognitif yang rendah. Pertanyaan yang diberikan hanya berorientasi pada jawaban di buku dan tidak mendorong peserta didik untuk memberikan umpan balik serta mereka tidak bisa menjelaskan ide atau pemikiran mereka sendiri. Pengembangan rasa ingin tahu dapat dilakukan melalui kegiatan diskusi yang bersifat open-ended, aktif dengan dukungan bahan ajar yang menarik dan pemanfaatan teknologi dalam pembelajaran.

Teknologi informasi dan komunikasi berpotensi menjadi sarana atau alat dalam proses pembelajaran untuk mengembangkan kemampuan kognitif, keterampilan, dan sikap peserta didik. Pembelajaran dalam Kurikulum 2013 menekankan pada penerapan ICT seperti media powerpoint, aplikasi berbasis flash, maupun internet. Berdasarkan survei dari Asosiasi Penyelenggara Jasa Internet Indonesia (APJII) pada tahun 2017, pengguna mengakses internet dalam berbagai layanan, termasuk layanan chatting dengan persentase terbesar daripada layanan lain. Hasil survei membuktikan bahwa penggunaan internet dalam bidang pendidikan masih belum optimal dilakukan.
Berdasarkan hasil observasi yang dilakukan di SMP Negeri 1 Jombang, penggunaan ICT dalam pembelajaran masih belum optimal. Sekolah memiliki fasilitas berupa hotspot, namun guru masih menggunakan media seperti powerpoint dan video dalam pembelajaran IPA. Website menjadi salah satu media yang dapat digunakan oleh guru dalam menyampaikan materi pembelajaran. Penggunaan website mampu memberikan kondisi pembelajaran IPA yang menarik dan menyenangkan bagi peserta didik. Menurut (Maharani \& Dewi, 2015; Stanojevic, Cenić, \& Cenić, 2018) bahwa penggunaan website memberikan kemudahan dalam peserta didik untuk mengakses berbagai sumber informasi di mana saja dan kapan saja, menumbuhkan rasa tertarik peserta didik dalam belajar IPA, serta berpengaruh positif terhadap motivasi dan rasa ingin tahu peserta didik.

Pemanfaatan ICT dalam pembelajaran dapat dilakukan oleh guru melalui bahan ajar seperti lembar kerja peserta didik. Lembar kerja peserta didik berisi kegiatan kerja yang menumbuhkan rasa ingin tahu, kemampuan berpikir siswa, dan keterampilan dalam berkomunikasi. Lembar Kerja Peserta Didik (LKPD) yang digunakan di sekolah hanya berisi latihan soal yang melatih peserta didik dalam kemampuan kognitif tingkat rendah dan membuat ketertarikan siswa pada pembelajaran IPA menurun (Widowati, Nurohman, \& Anjarsari, 2017). Lembar kerja yang mampu menarik perhatian peserta didik dalam pembelajaran IPA seharusnya menarik dari segi tampilan dan kegiatan, kombinasi dengan teknologi dan bersifat kontekstual.

Kontekstual dalam pembelajaran dapat diwujudkan dengan integrasi potensi lokal di suatu daerah. Potensi lokal merupakan suatu potensi yang dimiliki oleh suatu daerah berupa sumber daya alam, industri, budaya, jasa, kreasi seni, dan tradisi yang mendukung perekonomian penduduk sekitar (Anisa, 2017) (Kanzunnudin, 2014).

Potensi lokal dapat menjadi tema menarik untuk pembelajaran IPA. Integrasi potensi lokal dalam LKPD masih sangat minim dijumpai. Hal tersebut disebabkan oleh beberapa kendala seperti kurangnya wawasan mengenai potensi lokal di daerahnya, guru belum paham cara integrasi potensi lokal dalam sebuah bahan ajar, serta beban mengajar guru yang banyak dan fasilitas yang belum memadai (Wilujeng, 2016). Integrasi potensi lokal dalam pembelajaran mampu menumbuhkan rasa ingin tahu dalam diri peserta didik. Hal tersebut sejalan dengan penelitian 
yang dilakukan oleh (Ilma \& Wijarini, 2017) bahwa bahan ajar dengan integrasi potensi lokal dapat meningkatkan rasa ingin tahu dan minat belajar peserta didik terhadap IPA. Integrasi potensi lokal dalam pembelajaran tercantum dalam Undang-Undang Nomor 20 tahun 2003 tentang sistem pendidikan nasional yang menyatakan bahwa kurikulum dalam setiap jenjang dan jenis pendidikan dikembangkan sesuai dengan potensi daerah (Presiden Republik Indonesia, 2003). Integrasi potensi lokal dalam pembelajaran mampu memberikan wawasan kepada peserta didik sehingga mereka mampu mengolah potensi lokal menjadi hal yang lebih bermakna. Potensi lokal yang diintegrasikan dalam penelitian ini yaitu industri gula dari tebu atau pabrik gula Djombang Baru. Pabrik gula merupakan industri yang mengolah tebu menjadi gula kristal putih melalui berbagai proses kimiawi maupun fisika.

Berdasarkan masalah yang telah diuraikan, maka perlu dikembangkan web-LKPD IPA terintegrasi potensi lokal. Tujuan dari penelitian ini yaitu mengetahui kelayakan web-LKPD IPA terintegrasi potensi lokal dan mengetahui keefektifan web-LKPD IPA terintegrasi potensi lokal terhadap rasa ingin tahu peserta didik.

\section{METODE}

Penelitian ini merupakan jenis penelitian dan pengembangan (R\&D) dengan menggunakan model Four-D (Thiagarajan, Semmel, \& Semmel, 1974). Tahap 4D dari penelitian ini meliputi define, design, develop, dan disseminate. Produk yang dikembangkan berupa lembar kerja peserta didik berbasis website terintegrasi potensi lokal.

Uji coba produk dilaksanakan pada bulan Februari 2019 di SMP Negeri 1 Jombang. Pemilihan tempat uji coba disesuaikan dengan potensi lokal yang dipilih. Subjek uji coba adalah peserta didik kelas VII semester genap tahun ajaran 2018/2019. Subjek uji coba terbatas adalah 9 peserta didik kelas VII dengan kemampuan akademik rendah, sedang, dan tinggi. Uji coba terbatas bertujuan untuk mengetahui respon peserta didik terhadap keterbacaan produk. Uji coba dilanjutkan dengan uji coba lapangan menggunakan metode quasi eksperimen dengan pretest-posttest control group design. Subjek uji coba lapangan adalah 60 peserta didik meliputi 30 peserta didik kelas VII A dan kelas VII F. Pemilihan sampel uji coba lapangan dilakukan secara acak dengan hasil kelas VII A sebagai kelas eksperimen (pembelajaran dengan web-
LKPD IPA) dan kelas VII F sebagai kelas kontrol (pembelajaran konvensional oleh guru).

Instrumen pengumpulan data yang digunakan yaitu instrumen non tes berupa (1) lembar wawancara untuk studi pendahuluan; (2) lembar penilaian kelayakan produk untuk validator ahli materi dan media; (3) lembar kepraktisan untuk menilai kepraktisan penggunaan produk dalam pembelajaran; (4) angket keterbacaan untuk mengetahui respon peserta didik terhadap produk serta (5) lembar observasi rasa ingin tahu untuk mengukur rasa ingin tahu peserta didik selama pembelajaran dengan web-LKPD IPA. Lembar observasi rasa ingin tahu berisi tiga indikator yang dijabarkan masing-masing indikator berisi empat pernyataan. Pengamatan dilakukan oleh dua observer setiap proses pembelajaran. Observasi terhadap rasa ingin tahu peserta didik dilakukan sebanyak tiga kali. Observasi awal (pretest) hanya dilakukan pada satu kali pertemuan. Indikator rasa ingin tahu yang diukur yaitu mencari informasi dari berbagai sumber, tertarik dalam pembelajaran IPA, dan menanyakan kegiatan pembelajaran (Erdogan, 2017; Kementerian Pendidikan Nasional Republik Indonesia, 2008; Nuvitalia, Saptaningrum, Patonah, Khumaedi, \& Rusilawati, 2016; Spektor-Levy, Baruch, \& Mevarech, 2013). Sebelum digunakan dalam penelitian, instrumen yang digunakan dalam penelitian ini dilakukan analisis validasi.

Uji coba lapangan menggunakan pretestposttest control group design (Sugiyono, 2008). Pemilihan sampel dilakukan secara acak, kemudian kedua sampel diuji sebelum dan setelah perlakuan dengan observasi. Data kelayakan web-LKPD IPA dan kepraktisan oleh praktisi dianalisis secara kualitatif menggunakan skala dengan empat kriteria yaitu sangat baik, baik, cukup baik, dan kurang baik. Sedangkan data angket respon peserta didik dianalisis berdasarkan persentase peserta didik dengan respon positif. Data hasil kelayakan dan penilaian oleh praktisi diubah menjadi data kuantitatif (Arikunto, 2002) dengan Persamaan 1.

$\bar{X}=\frac{\Sigma x i}{N}$

Berdasarkan Persamaan 1, $X$ adalah Mean (rerata) skor penilaian, $\sum x i$ adalah jumlah total skor tiap komponen, dan $\mathrm{N}$ merupakan banyaknya penilai. Data hasil kelayakan dan kepraktisan kemudian dikonversi menjadi skala kualitatif dengan kriteria yang terdapat pada Tabel 1. 
Tabel 1. Pedoman Konversi Skor Kualitatif

\begin{tabular}{ccl}
\hline \multicolumn{1}{c}{ Rentang Skor } & Nilai & \multicolumn{1}{c}{ Kategori } \\
\hline$X \geq \bar{X}+1 . s b x$ & A & Sangat Baik \\
$\bar{X}+1 . s b x>X \geq \bar{X}$ & B & Baik \\
$X>X \geq \bar{X}-1 . s b x$ & C & Cukup Baik \\
$X<\bar{X}-1 . s b x$ & D & Kurang Baik \\
\hline
\end{tabular}

(Mardapi, 2008)

Keefektifan web-LKPD IPA terintegrasi potensi lokal dianalisis menggunakan skor gain ternormalisasi dan independent sample t-test. Skor gain ternormalisasi diperoleh Persamaan 2.

$<$ g $>=\frac{<\% \text { post }>-<\% \text { pre }>}{100-<\% \text { pre }>}$

Berdasarkan Persamaan 1, $\langle\mathrm{g}\rangle$ adalah rata-rata skor gain. $\langle \%$ post $>$ adalah rata-rata persentase skor posttest peserta didik. Sedangkan <\% pre> merupakan rata-rata persentase skor pretest peserta didik. Skor gain yang telah diperoleh kemudian dikategorikan sesuai dengan Tabel 1.

Tabel 1. Kategori Rata-Rata Skor Gain

\begin{tabular}{cc}
\hline Score $\langle\mathrm{g}\rangle$ & Kategori \\
\hline$<\mathrm{g}>\geq 0.7$ & Tinggi \\
$0.7><\mathrm{g}>\geq 0.3$ & Sedang \\
$\langle\mathrm{g}><0.3$ & Rendah \\
\hline
\end{tabular}

(Hake, 1999)

Uji keefektifan menggunakan uji independent sample $t$ test. Uji tersebut dapat dilakukan apabila uji prasyarat terpenuhi yaitu uji normalitas dan homogenitas univariat. Uji prasyarat dilakukan menggunakan SPSS 16. Uji normalitas bertujuan untuk menguji apakah sampel data yang digunakan berdistribusi normal atau tidak, sedangkan uji homogenitas dilakukan untuk mengetahui apakah populasi kedua sampel homogen atau tidak.

Uji normalitas dilakukan dengan ShapiroWilks pada taraf signifikansi 5\% (Razali \& Wah, 2011; Royston, 1992). Data berasal dari populasi yang berdistribusi normal apabila nilai signifikansi > 0.05. Uji homogenitas menggunakan Levene's Test pada taraf signifikansi 0.05. Data berasal dari populasi yang homogen apabila memenuhi nilai signifikansi $>0.05$.

Setelah uji prasyarat terpenuhi, maka dapat dilanjutkan uji independent sampe t test dengan hipotesis, $\mathrm{H}_{\mathrm{o}}$ adalah tidak terdapat perbedaan penggunaan web-LKPD IPA terintegrasi potensi lokal terhadap rasa ingin tahu. $\mathrm{H}_{\mathrm{a}}$ adalah terdapat perbedaan penggunaan web-LKPD IPA terintegrasi potensi lokal terhadap rasa ingin tahu.

\section{Prosedur Pengembangan}

Tahap penelitian dan pengembangan (Thiagarajan et al., 1974) yaitu Pertama, tahap define dibagi menjadi empat analisis yaitu analisis kebutuhan, analisis peserta didik, dan analisis tugas. Analisis tugas bertujuan untuk memperoleh informasi tentang proses pembelajaran, bahan ajar dan sumber belajar yang digunakan, dan permasalahan terkait penyusunan bahan ajar oleh guru melalui wawancara dan observasi di SMP Negeri 1 Jombang. Analisis peserta didik untuk memperoleh informasi mengenai rasa ingin tahu peserta didik dalam pembelajaran. Analisis tugas meliputi analisis kurikulum, analisis materi, dan penyusunan peta konsep. Analisis kurikulum berisi Kompetensi Inti (KI), Kompetensi Dasar (KD), indikator pembelajaran, dan tujuan pembelajaran yang disesuaikan dengan potensi lokal yang dipilih yaitu pabrik gula di Kabupaten Jombang. Analisis materi bertujuan untuk mengidentifikasi fakta, konsep, prinsip, dan teori dalam materi pokok serta terkait dengan potensi lokal. Peta konsep disusun disusun berdasarkan hasil analisis materi yang berisi konsep, fakta, dan prinsip dalam pembelajaran materi pencemaran lingkungan.

Kedua, tahap design meliputi langkah pemilihan media dan format, serta rancangan awal produk. Dalam pemilihan media dan format, peneliti memilih weblog Wordpress sebagai wadah penyampai media pembelajaran, membuat struktur web-LKPD IPA dan tampilan. Selanjutnya penyusunan dilanjutkan dengan membuat web-LKPD IPA, perangkat pembelajaran, serta konten materi yang dipadukan dengan potensi lokal. Pengembangan web-LKPD IPA termasuk membuat akun di wordpress, membuat laman, mengatur tata letak gambar dan video, membuat postingan serta membuat plugin untuk evaluasi.

Ketiga, tahap develop, langkah yang dilakukan yaitu validasi web-LKPD IPA oleh validator ahli materi dan ahli media, penilaian oleh praktisi, kemudian uji coba terbatas dan uji coba lapangan. Validasi oleh ahli dilakukan untuk mengetahui kelayakan terhadap web-LKPD IPA, sedangkan penilaian oleh praktisi atau guru IPA dilakukan untuk mengetahui kepraktisan dari web-LKPD IPA dalam pembelajaran.

\section{HASIL DAN PEMBAHASAN}

Hasil dari penelitian dan pengembangan berupa web-LKPD IPA terintegrasi potensi lokal. Potensi lokal yang digunakan yaitu pabrik gula di 
Kabupaten Jombang. Materi yang digunakan yaitu KD 3.8 dan KD 4.8 kelas VII SMP mengenai pencemaran lingkungan dan dampaknya bagi ekosistem. Karakteristik materi pokok relevan dengan potensi lokal yang digunakan yaitu pabrik gula di Kabupaten Jombang. Format web-LKPD IPA yang dikembangkan meliputi judul; sistem navigasi; menu pages yaitu beranda, deskripsi, lembar kerja peserta didik, uji kompetensi, dan biodata penulis; konten berupa halaman website; serta widget berupa informasi tambahan dan kalender. Web-LKPD IPA terintegrasi potensi lokal dapat diakses pada laman sainspedia.com. Tampilan web-LKPD IPA dapat dilihat pada Gambar 1.

Web-LKPD IPA yang dikembangkan terdiri dari tiga lembar kerja yang disusun sesuai dengan analisis kurikulum dan analisis materi. Lembar kerja 1 berisi kegiatan untuk materi pencemaran air berupa praktikum mengenai dampak limbah cair pabrik gula terhadap ekosistem dan kehidupan makhluk hidup pada ekosistem perairan, lembar kerja 2 berisi kegiatan untuk materi pencemaran tanah berupa kegiatan diskusi tentang limbah cair pabrik gula yang mencemari lahan pertanian, dan lembar kerja 3 berisi kegiatan untuk materi pencemaran udara berupa kegiatan diskusi tentang limbah gas dan debu yang mencemari udara di sekitar pabrik. Setiap lembar kerja peserta didik disesuaikan dengan konten dalam potensi lokal yang digunakan. Setiap lembar kerja berisi informasi pen- dukung untuk membantu peserta didik dalam mengerjakan bahan diskusi. Peserta didik menggunakan web-LKPD IPA dengan memasukkan hasil kegiatan melalui plugin yang disediakan yaitu Google Form. Penggunaan web-LKPD IPA dilakukan secara berkelompok dengan masingmasing anggota sebanyak 5-6 peserta didik.

\section{Hasil Kelayakan Produk}

Penilaian kelayakan web-LKPD IPA dilakukan dengan memberikan lembar validasi kepada ahli materi dan ahli media. Proses validasi dilakukan untuk mengetahui kelayakan produk yang dikembangkan berdasarkan penilaian oleh validator ahli. Kelayakan web-LKPD IPA diperoleh dari penilaian serta saran dari validator ahli. Penilaian dilakukan oleh dua dosen ahli yaitu ahli materi dan ahli media.

Komponen penilaian ahli materi meliputi isi, penyajian, kebahasaan, dan karakteristik. Hasil penilaian ahli materi disajikan pada Tabel 2 . Berdasarkan Tabel 2 penilaian oleh ahli materi didapatkan hasil bahwa rata-rata skor yang diperoleh sebesar 62 dan tergolong pada kategori sangat baik pada konversi skor kualitatif. Aspek penilaian karakteristik berupa integrasi potensi lokal dalam pembelajaran. Integrasi potensi lokal dalam pembelajaran tidak hanya sebagai sumber belajar dari pembelajaran, namun sebagai objek permasalahan yang membantu peserta didik untuk tertarik dalam belajar IPA. Potensi lokal yang

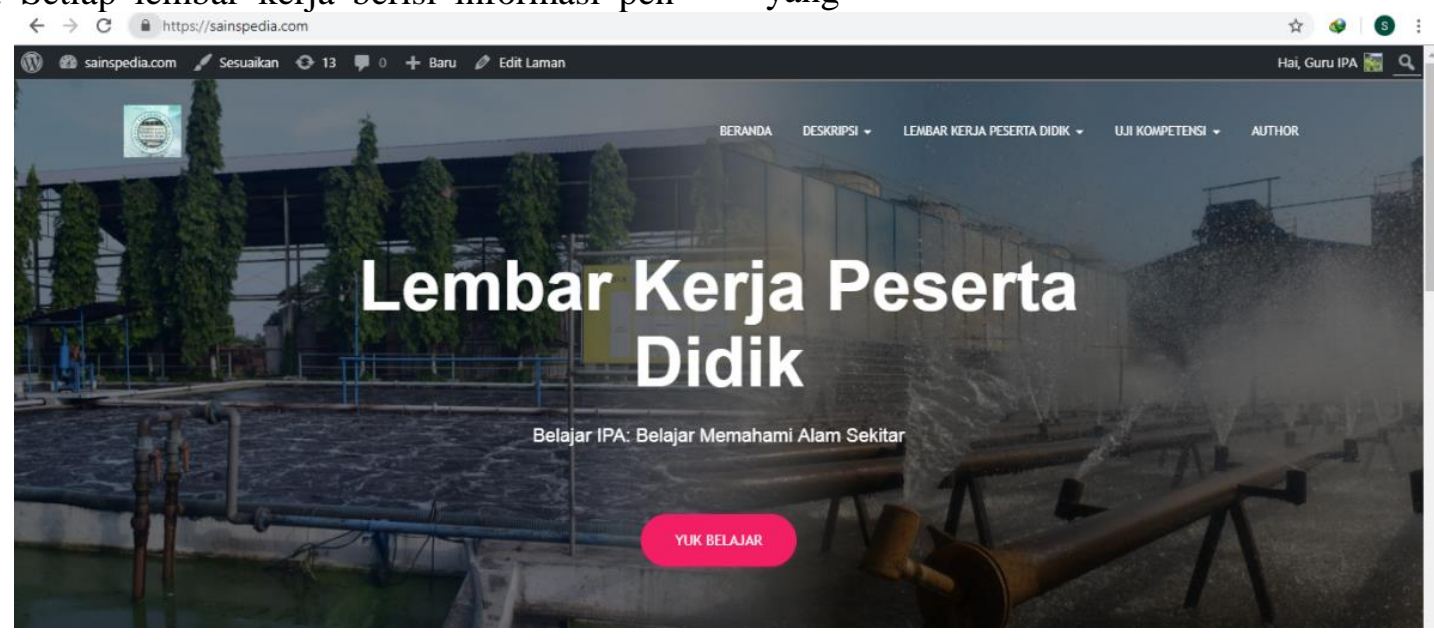

Gambar 1. Tampilan Web-LKPD IPA

Tabel 2. Hasil Penilaian Kelayakan oleh Ahli Materi

\begin{tabular}{clcccc}
\hline No. & \multicolumn{1}{c}{ Aspek } & Skor & Skor Maksimal & Nilai & Kategori \\
\hline 1. & Isi & 20 & 20 & A & Sangat Baik \\
2. & Penyajian & 16 & 12 & A & Sangat Baik \\
3. & Kebahasaan & 15 & 12 & A & Sangat Baik \\
4. & Karakteristik & 11 & 9 & A & Sangat Baik \\
& Jumlah & 62 & 48 & A & Sangat Baik \\
\hline
\end{tabular}


Penilaian oleh ahli media terdiri dari dua aspek yaitu kegrafikan dan karakteristik. Hasil penilaian kelayakan oleh ahli media dapat dilihat pada Tabel 3. Berdasarkan Tabel 3 penilaian oleh ahli media didapatkan hasil rata-rata skor yang diperoleh sebesar 38 dan tergolong pada kategori sangat baik. Hasil penilaian web-LKPD IPA oleh ahli secara keseluruhan memperoleh skor 89 dan tergolong pada kategori sangat baik. Selain memberikan penilaian, validator ahli juga memberikan saran dan komentar untuk perbaikan webLKPD IPA. Saran dari validator ahli media seperti (1) kalimat panduan dalam web dibuat lebih jelas dan detail; (2) peta konsep memiliki resolusi kecil dan tulisan tidak terbaca; (3) kata "welcome" disamakan dengan kata yang lain; (4) tata letak laman dan widget diperbaiki sehingga tidak menimbulkan kebingungan peserta didik; dan (5) hasil soal evaluasi dari pembelajaran sebelumnya dapat ditampilkan untuk pembelajaran lebih lanjut. Saran dari validator ahli media dilakukan revisi untuk memperoleh produk yang layak digunakan dalam pembelajaran IPA. Menurut Sudarwati, Khanafiyah, \& Sugiyanto (2017) kualitas website yang baik dapat dilihat dari tiga aspek yaitu aspek teknik seperti pengoperasian, konten atau isi, dan desain seperti tampilan, jenis huruf, dan tema yang digunakan. Ketiga aspek tersebut sudah terdapat dalam penilaian web-LKPD IPA pada aspek kegrafikan, sehingga web-LKPD IPA dinyatakan layak oleh ahli media.

Jenis dan ukuran huruf sangat berpengaruh terhadap perhatian dan antusias peserta didik dalam menggunakan web-LKPD IPA. Jenis dan ukuran huruf yang serasi membantu peserta didik dalam memahami bacaan dengan cepat sehingga mereka mudah mendapatkan informasi yang bermakna (Purwanti, Prihanta, Muizzudin, \& Permana, 2018). Selain itu, juga memberikan kemudahan peserta didik dalam memahami bahan diskusi.

Penilaian dilanjutkan dengan penilaian kepraktisan oleh guru IPA. Penilaian kepraktisan dilakukan oleh dua guru SMP Negeri 1 Jombang. Hasil penilaian kelayakan oleh guru IPA disajikan pada Tabel 4. Hasil dari penilaian kepraktisan oleh guru IPA diperoleh skor sebesar 56 dan tergolong pada kategori sangat baik. Selain memberikan penilaian, guru sebagai praktisi juga memberikan saran sehingga web-LKPD IPA dapat digunakan untuk pembelajaran selanjutnya. Saran dari guru IPA meliputi susunan kalimat dalam bahan diskusi diperbaiki dan istilah dalam web-LKPD IPA lebih diperjelas.

\section{Uji Coba Terbatas}

Uji coba terbatas dilakukan setelah webLKPD IPA dinyatakan layak berdasarkan hasil validasi. Uji coba terbatas dilakukan untuk mengetahui respon dari peserta didik terhadap keterbacaan produk. Hasil uji keterbacaan disajikan pada Tabel 5.

Hasil uji keterbacaan secara keseluruhan menunjukkan bahwa 93\% peserta didik memberikan respon positif terhadap web-LKPD IPA. Hasil analisis menunjukkan bahwa $100 \%$ peserta didik merasa tertarik dalam belajar IPA menggunakan web-LKPD IPA. Hal tersebut sejalan dengan penelitian yang dilakukan oleh Knight \& Glaser (2012) bahwa tampilan serta animasi dalam website mampu menarik perhatian peserta didik untuk belajar.

Tabel 3. Hasil Penilaian Kelayakan oleh Ahli Media

\begin{tabular}{clcccc}
\hline No. & \multicolumn{1}{c}{ Aspek } & Skor & Skor Maksimal & Nilai & Kategori \\
\hline 1. & Kegrafikan & 27 & 21 & A & Sangat Baik \\
2. & Karakteristik & 11 & 9 & A & Sangat Baik \\
& Jumlah & 38 & 30 & A & Sangat Baik \\
\hline
\end{tabular}

Tabel 4. Penilaian Kepraktisan oleh Guru IPA

\begin{tabular}{clcccc}
\hline No. & \multicolumn{1}{c}{ Aspek } & Skor & Skor Maksimal & Nilai & Kategori \\
\hline 1. & Kegrafikan & 18.5 & 15.0 & A & Sangat Baik \\
2. & Karakteristik & 8.0 & 6.0 & A & Sangat Baik \\
3. & Kebahasaan & 15.0 & 12.0 & A & Sangat Baik \\
4. & Kepraktisan & 4.0 & 3.0 & A & Sangat Baik \\
5. & Karakteristik & 10.5 & 9.0 & A & Sangat Baik \\
& Jumlah & 56.0 & 45.0 & A & Sangat Baik \\
\hline
\end{tabular}


Jurnal Inovasi Pendidikan IPA, 5 (1), 2019 - 104

Maulidiyani Fuadati, Insih Wilujeng

Tabel 5. Hasil Uji Keterbacaan

\begin{tabular}{|c|c|c|c|c|}
\hline \multirow{2}{*}{ No. } & \multirow{2}{*}{ Pernyataan } & \multicolumn{2}{|c|}{ Penilaian } & \multirow{2}{*}{$\begin{array}{l}\text { Persentase } \\
\quad(\%)\end{array}$} \\
\hline & & Ya & Tidak & \\
\hline 1. & Judul dalam web-LKPD IPA menarik dan komunikatif & 8 & 1 & 89 \\
\hline 2. & Warna tulisan dengan background sudah serasi & 8 & 2 & 89 \\
\hline 3. & Jenis dan ukuran huruf sudah seimbang sehingga mudah dibaca & 7 & 3 & 78 \\
\hline 4. & $\begin{array}{l}\text { Menu dan tombol dalam produk berfungsi dengan baik dan mudah } \\
\text { dipahami }\end{array}$ & 9 & 0 & 100 \\
\hline 5. & Letak dan tampilan menu tidak membuat saya bingung & 8 & 1 & 89 \\
\hline 6. & Saya mudah memahami petunjuk penggunaan web-LKPD IPA & 8 & 1 & 89 \\
\hline 7. & Alamat web mudah untuk diingat & 9 & 0 & 100 \\
\hline 8. & Saya dapat dengan mudah membuka halaman web-LKPD IPA & 9 & 0 & 100 \\
\hline 9. & Web-LKPD IPA dapat dioperasikan dengan mudah & 9 & 0 & 100 \\
\hline 10. & $\begin{array}{l}\text { Resolusi/kualitas dari ilustrasi (gambar, animasi, dan video) sudah jelas } \\
\text { dan dapat dipahami dengan baik }\end{array}$ & 9 & 0 & 100 \\
\hline 11. & Saya tertarik untuk belajar IPA dengan menggunakan web-LKPD IPA & 9 & 0 & 100 \\
\hline 12. & $\begin{array}{l}\text { Kalimat dalam petunjuk belajar mudah dipahami dan tidak menimbulkan } \\
\text { kebingungan }\end{array}$ & 8 & 1 & 89 \\
\hline 13. & $\begin{array}{l}\text { Saya mudah dalam memahami materi pembelajaran dengan } \\
\text { menggunakan web-LKPD IPA }\end{array}$ & 9 & 0 & 100 \\
\hline 14. & $\begin{array}{l}\text { Informasi pendukung berupa gambar, wacana, video memudahkan saya } \\
\text { untuk memahami kegiatan kerja }\end{array}$ & 9 & 0 & 100 \\
\hline 15. & Susunan kata dan kalimat dalam produk sederhana dan mudah dipahami & 8 & 1 & 89 \\
\hline 16. & $\begin{array}{l}\text { Penggunaan istilah dalam produk mudah dipahami dan tidak } \\
\text { menimbulkan penafsiran ganda }\end{array}$ & 9 & 0 & 100 \\
\hline
\end{tabular}

Pemilihan tema dan penataan halaman web disesuaikan dengan kemudahan pengoperasian saat digunakan dalam pembelajaran di kelas. Hal tersebut dibuktikan dari $100 \%$ peserta didik menyatakan bahwa mereka mudah dalam mengoperasikan web-LKPD IPA dan 89\% menyatakan bahwa menu dan halaman yang disajikan tidak menimbulkan kebingungan. Media pembelajaran dengan tata letak yang baik, seimbang, dan kreatif memberikan kemudahan peserta didik dalam pengoperasiannya (Pantiwati, Wahyuni, \& Permana, 2017).

Materi yang digunakan dalam web-LKPD IPA serta terintegrasi dengan potensi lokal pabrik gula yaitu pencemaran lingkungan, berdasarkan hasil analisis angket menyatakan bahwa 100\% peserta didik merasa lebih mudah dalam memahami materi pembelajaran serta memudahkan dalam mencari berbagai sumber informasi untuk mendukung keterlaksanaan pembelajaran.

Kemudahan peserta didik dalam memahami materi pencemaran lingkungan didukung oleh adanya informasi pendukung serta video yang diberikan. Informasi pendukung berisi permasalahan untuk mendorong rasa ingin tahu peserta didik dalam mengerjakan bahan diskusi. Hal tersebut dibuktikan oleh penelitan dari (Sládek, Milér, \& Benárová, 2011) bahwa penggunaan animasi berupa gambar dan vieo dalam sebuah website mampu membangun perhatian siswa dan rasa tertarik dalam belajar IPA.

\section{Hasil Uji Coba Lapangan}

Uji coba lapangan dilakukan pada 30 peserta didik kelas VII A (kelas eksperimen) dan 30 peserta didik kelas VII F (kelas kontrol). Keefektifan web-LKPD IPA terhadap rasa ingin tahu peserta didik diukur dengan membandingkan rata-rata skor gain ternormalisasi. Hasil skor pretest dan posttest rasa ingin tahu dan hasil analisis skor gain ternormalisasi dapat dilihat pada Gambar 2 dan Gambar 3.

Berdasarkan Gambar 2 menunjukkan bahwa terdapat peningkatan skor pretest dan posttest. Peningkatan pada kelas eksperimen lebih besar daripada kelas kontrol. Peningkatan kelas eksperimen sebesar 21.67, sedangkan kelas kontrol mengalami peningkatan sebesar 13.69. Data tersebut juga didukung oleh skor gain ternormalisasi kelas ekpserimen lebih besar daripada kelas kontrol. Kelas eksperimen mendapatkan skor gain sebesar 0.36 pada kategori sedang, sedangkan kelas kontrol mendapatkan skor gain sebesar 0.20 pada kategori rendah. Berdasarkan analisis, skor gain ternormalisasi pada kelas eksperimen jauh lebih tinggi daripada kelas kontrol. Hal tersebut dikarenakan penggunaan lembar kerja peserta didik berbasis website dengan integrasi potensi lokal menjadi hal baru, menarik, dan 
bermakna bagi peserta didik. Pembelajaran pada kelas kontrol menggunakan pembelajaran klasikal (ceramah) dan lembar kerja oleh penerbit, sehingga rasa ingin tahu dan antusias peserta didik dalam belajar IPA kurang.

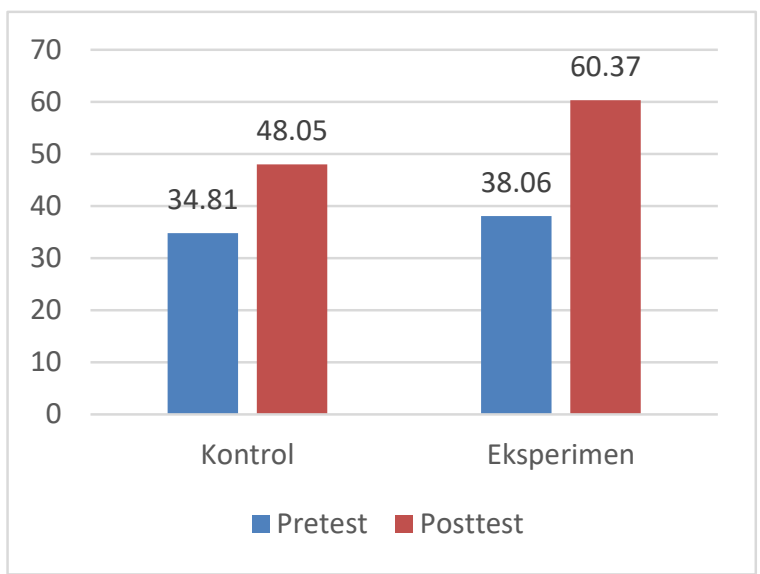

Gambar 2. Nilai Rata-Rata Rasa Ingin Tahu

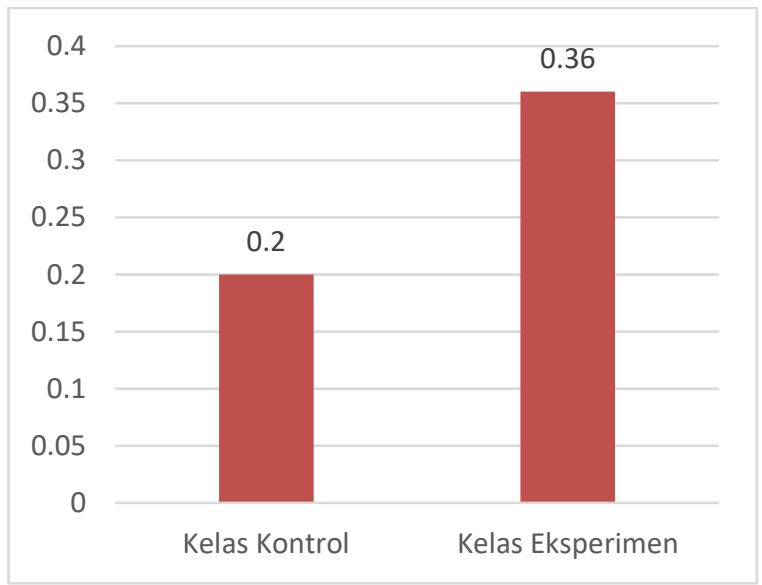

Gambar 3. Hasil Analisis Skor Gain Ternormalisasi

Hasil pengukuran skor rasa ingin tahu juga dilihat dari tiap indikator yang diukur. Rekapitulasi skor gain tiap indikator disajikan pada Tabel 9. Berdasarkan Tabel 9 dapat dilihat bahwa terjadi peningkatan skor rasa ingin tahu dalam setiap aspek. Peningkatan tersebut ditunjukkan dengan gain skor yang bernilai positif pada tiap aspek rasa ingin tahu. Masing-masing aspek rasa ingin tahu pada kelas kontrol tergolong pada kategori rendah, sedang, dan rendah. Sedangkan pada kelas eksperimen tergolong kategori sedang. Hal ini dikarenakan adanya penggunaan permasalahan dalam bahan diskusi di web-LKPD IPA yang memfasilitasi aspek-aspek rasa ingin tahu. Pertanyaan dalam bahan diskusi melibatkan kemampun berpikir tingkat tinggi sehingga peserta didik merasa tertantang dan menimbulkan keingintahuannya untuk mencari solusi permasalahan tersebut.

Aspek dengan peningkatan paling tinggi yaitu aspek tertarik dalam kegiatan pembelajaran IPA, hal ini dikarenakan konten dalam webLKPD IPA memberikan gambaran yang ada di lingkungan sekitar mereka berupa potensi lokal di Kabupaten Jombang. Rasa antusias dan tertarik dalam belajar IPA merupakan bagian dari rasa ingin tahu (Latiifani, Rinanto, \& Marjono, 2016; Pluck \& Johnson, 2011; Spektor-Levy et al., 2013).

Sebelum dilakukan uji keefektifan, terlebih dahulu dilakukan uji prasyarat yaitu uji normalitas dan uji homogenitas. Hasil uji normalitas univariat menggunaakan uji Shapiro-Wilks mendapatkan nilai signifikansi kelas kontrol sebesar 0.501 dan kelas eksperimen sebesar 0.121 . Nilai signifikansi yang diperoleh lebih dari 0.05 , sehingga sampel data yang digunakan berdistribusi normal. Uji homogenitas dilakukan dengan Levene's Test of Homogenity diperoleh nilai signifikansi sebesar 0.215 . Nilai signifikansi yang diperoleh lebih dari 0.05 , sehingga kedua sampel berasal dari populasi yang homogen. Hasil dari uji prasyarat sudah terpenuhi, sehingga dapat dilanjutkan untuk uji independent sample $t$ test.

Keefektifan web-LKPD IPA dilihat dari hasil uji independent sample t test terhadap skor gain ternormalisasi. Hasil uji independent sample $t$ test menunjukkan nilai sig. (2-tailed) sebesar 0.00 , nilai tersebut lebih kecil $(<0.05)$. Jadi dapat disimpulkan bahwa terdapat perbedaan yang signifikan antara kelas eksperimen dan kelas kontol. Dengan demikian web-LKPD IPA terintegrasi potensi lokal yang dikembangkan selain layak juga efektif dalam meingkatkan rasa ingin tahu peserta didik.

Tabel 9. Rekapitulasi Skor Gain Rasa Ingin Tahu

\begin{tabular}{clcccccc}
\hline \multirow{2}{*}{ No. } & \multirow{2}{*}{ Aspek } & \multicolumn{3}{c}{ Kelas Kontrol } & \multicolumn{3}{c}{ Kelas Eksperimen } \\
\cline { 3 - 7 } & & Pre & Post & Gain & Pre & Post & Gain \\
\hline 1. & Mencari informasi dari berbagai sumber & 40.00 & 55.83 & 0.26 & 51.67 & 68.89 & 0.36 \\
2. & Tertarik dalam kegiatan pembelajaran & 57.50 & 70.83 & 0.31 & 60.00 & 77.50 & 0.44 \\
3. & Menanyakan kegiatan pembelajaran & 4.17 & 10.28 & 0.06 & 2.50 & 31.67 & 0.30 \\
\hline
\end{tabular}


Hal tersebut sejalan dengan penelitian yang dilakukan oleh Hidayah, Lumowa, \& Boleng (2018) bahwa pembelajaran berbasis website mampu mengembangkan motivasi dan rasa tertarik peserta didik dalam belajar IPA. Pembelajaran dengan website juga memberikan kesempatan dan kemudahan dalam mencari informasi dari berbagai sumber sehingga peserta didik lebih mudah memahami materi pembelajaran (Schunk, Pintrich, \& Meece, 2008; Yulianti, 2017). Hal tersebut sejalan dengan penelitian Shabrina \& Kuswanto (2018) bahwa penggunaan website sebagai media penyampai bahan ajar dapat membentuk situasi belajar yang menarik, inovatif, efektif, dan kreatif. Media seperti video yang ditampilkan dalam web-LKPD IPA membantu peserta didik dalam memahami konsepkonsep dalam materi yang diajarkan. Selain itu, menurut penelitian dari Sudarwati et al. (2017) bahwa penggunaan website memberikan kesempatan peserta didik dan guru untuk saling berinteraksi dan berkomunikasi secara online melalui forum diskusi yang disediakan. Oleh karena itu pengembangan web-LKPD IPA ini menjadi sebuah inovasi baru dalam pengembangan bahan ajar dengan integrasi teknologi. Kombinasi pembelajaran antara teknologi dengan pendekatan yang sesuai serta konten pembelajaran mampu memberikan manfaat dalam membentuk pendidikan dengan kualitas (Pritasari \& Jumadi, 2018).

Menurut Nugraheni dan Dina (2017), pembelajaran dengan website tetap memerlukan panduan dari guru dalam berinteraksi secara langsung dengan peserta didik. Panduan dari guru diperlukan saat peserta didik mengalami kesulitan dalam pengoperasian web-LKPD IPA dan juga saat kesulitan dalam memahami materi pembelajaran.

Kegiatan di dalam lembar kerja peserta didik berisi kegiatan yang mendukung kemampuan berpikir serta mengembangkan karakter dalam diri peserta didik melalui pengetahuan yang telah dimiliki oleh peserta didik dengan memanfaatkan berbagai sumber belajar sehingga pembelajaran lebih bermakna. Kegiatan yang terdapat dalam web-LKPD IPA terintegrasi dengan potensi lokal. Potensi lokal dapat menjadi tema yang menarik untuk pembelajaran serta dapat dijadikan sebuah permasalahan. Hal itu sejalan dengan penelitian oleh Pluck \& Johnson (2011) jika peserta didik diberikan permasalahan, keingintahuan mereka untuk mencari solusi permasalahan akan meningkat seiring dengan tingkat permasalahan. Penggunaan potensi lokal dalam pembelajaran dapat meningkatkan curiosity (rasa ingin tahu) peserta didik SMP. Potensi lokal yang diintegrasikan dalam pembel-ajaran dapat menumbuhkan karakter peserta didik untuk lebih menghargai budaya maupun sumber daya yang berada di lingkungan sekitarnya.

Integrasi potensi lokal dalam pembelajaran juga dilakukan oleh Anisa (2017) yang menyatakan bahwa pembelajaran dengan potensi lokal membantu peserta didik belajar secara kontekstual dan mendapatkan pengalaman belajar secara langsung. Menurut Lase, Sipahutar, \& Harahap (2016) lembar kerja peserta didik terintegrasi potensi lokal di Pulau Nias dapat menarik perhatian peserta didik dalam pembelajaran serta memberikan wawasan dan pengalaman baru kepada peserta didik karena materi yang disajikan berkaitan dengan potensi lokal Nias.

\section{SIMPULAN}

Berdasarkan hasil analisis data yang telah dilakukan, dapat disimpulkan bahwa terdapat perbedaan rasa ingin tahu kelas eksperimen dan kelas kontrol. Perbedaan tersebut dapat dilihat berdasarkan hasil uji independent sample t-test menunjukkan nilai sig $(2$-tailed $)<0.05$. Hal tersebut menunjukkan bahwa pembelajaran menggunakan web-LKPD IPA terintegrasi potensi lokal efektif meningkatkan rasa ingin tahu. Keefektifan tersebut dikarenakan pembelajaran dengan menggunakan web-LKPD IPA menjadi hal yang baru bagi peserta didik, sehingga mereka lebih tertarik dan antusias dalam belajar IPA dan membantu mereka untuk mengenal potensi lokal di Kabupaten Jombang.

\section{DAFTAR PUSTAKA}

Anisa, A. (2017). Meningkatkan keterampilan berpikir kritis peserta didik melalui pembelajaran IPA berbasis potensi lokal Jepara. Jurnal Inovasi Pendidikan IPA, $3(1)$, https://doi.org/10.21831/jipi.v3i1.8607

Arikunto, S. (2002). Metode penelitian. Jakarta: Rineka Cipta.

Dwianto, A., Wilujeng, I., Prasetyo, Z. K., \& Suryadarma, I. G. P. (2017). The development of science domain based learning media which is integrated with local potention to improve science process skill and scientific attitude. Jurnal Pendidikan IPA Indonesia, 6(1). https://doi.org/10.15294/jpii.v6i1.7205

Erdogan, I. (2017). Turkish elementary students' classroom discourse: Effects of structured 
and guided inquiry experiences that stimulate student questions and curiosity. International Journal of Environmental and Science Education, 12(5), 1111-1137.

Fithriyyati, N., \& Maryani, I. (2018). Science lesson plan evaluation for 7th grade secondary school: A learning process reflection. Psychology, Evaluation, and Technology in Educational Research, 1(1), 9-18. https://doi.org/10.33292/petier.v1i1.17

Hake, R. R. (1999). Analyzing change/Gain scores. Retrieved from http://www.physics.indiana.edu/ sdi/Anal yzingChange-Gain.pdf

Hidayah, M. U., Lumowa, S. V. T., \& Boleng, D. T. (2018). Developing the archaebacteria and eubacteria web-based learning media for high school students. JPBI (Jurnal Pendidikan Biologi Indonesia), 4(2), 179188. https://doi.org/10.22219/jpbi.v4i2.5750

Ilma, S., \& Wijarini, F. (2017). Developing of environmental education textbook based on local potencies. JPBI (Jurnal Pendidikan Biologi Indonesia), 3(3), 194. https://doi.org/10.22219/jpbi.v3i3.4540

Kementerian Pendidikan Nasional Republik Indonesia. (2008). Pendidikan karakter untuk bangsa. Jakarta: Direktorat Jendral Pendidikan Dasar Kementrian Pendidikan Nasional. Character And Independence.

Kanzunnudin, M., \& Oktavianti, I. (2014). Mengikis diskriminasi anak di sekolah melalui pengembangan sosial siswa pada pembelajaran IPS berbasis keunggulan lokal kudus melalui penerapan recriprocal learning berbantu media dan metrik ingatan. Seminar Nasional, 70-79. Kudus: Universitas Muria Kudus.

Knight, C., \& Glaser, J. (2012, April). When typography speaks louder than words. Smashing Magazine. Retrieved from https://www.smashingmagazine.com/201 2/04/when-typography-speaks-louderthan-words/

Lase, N. K., Sipahutar, H., \& Harahap, F. (2016). Pengembangan Lembar Kegiatan Siswa (LKS) berbasis potensi lokal pada mata pelajaran Biologi SMA kelas XII. Jurnal Pendidikan Biologi, 5(2), 99-107. https://doi.org/10.24114/jpb.v5i2.4305

Latiifani, C., Rinanto, Y., \& Marjono, M. (2016).
Penerapan model pembelajaran inkuiri terbimbing untuk meningkatkan rasa ingin tahu (curiosity) siswa kelas X MIPA 2 SMA Negeri 6 Surakarta tahun pelajaran 2015/2016. BIO-PEDAGOGI: Jurnal Pembelajaran Biologi, 5(2), 1-6. Retrieved from https://jurnal.uns.ac.id/pdg/article/view/54 14

Maharani, D. W., \& Dewi, N. R. (2015). The implementation of science inquiry-based website oriented by cultural deviance solution to instill students' character and independence. Jurnal Pendidikan IPA Indonesia, 4(1), 25-30. https://doi.org/10.15294/jpii.v4i1.3497

Mardapi, D. (2008). Teknik penyusunan instrumen tes dan nontes. Yogyakarta: Mitrs Cendikia Offset.

Nugraheni, A. R. E., \& Dina, D. (2017). Pengaruh penerapan pembelajaran elearning terhadap kemandirian dan minat belajar mahasiswa pada mata kuliah wawasan dan kajian MIPA. Edusains UIN Syarif Hidayatullah, 9(1), 111-116. https://doi.org/10.15408/es.v9i1.5458

Nuvitalia, D., Saptaningrum, E., Patonah, S., Khumaedi, K., \& Rusilawati, A. (2016). Dimensi rasa ingin tahu siswa melalui pendekatan saintifik berbantuan alat peraga penjernihan air. Phenomenon: Jurnal Pendidikan MIPA, 6(2), 10-17. https://doi.org/10.21580/phen.2016.6.2.10 77

Pantiwati, Y., Wahyuni, S., \& Permana, F. H. (2017). Instructional model of natural science in junior high schools, BatuMalang. Journal of Education and Practice, 8(8), 117-123. Retrieved from https://www.iiste.org/Journals/index.php/J EP/article/view/36040

Pluck, G., \& Johnson, H. L. (2011). Stimulating curiosity to enhance learning. GESJ: Education Sciences and Psychology, 2(19). Retrieved from http://eprints.whiterose.ac.uk/74470/

Presiden Republik Indonesia. Undang-Undang Republik Indonesia nomor 20 tahun 2003 tentang sistem pendidikan nasional, Pub. L. No. 20, Undang-Undang Republik Indonesia 26 (2003). Indonesia.

Pritasari, A. C., \& Jumadi, J. (2018). Development of science learning tool 
based on problem based learning with

Google Classroom to improve argumentation skill. Biosaintifika: Journal of Biology \& Biology Education, 10(2), 348-355.

https://doi.org/10.15294/biosaintifika.v10i 2.14320

Purwanti, E., Prihanta, W., Muizzudin, M., \& Permana, F. H. (2018). Penerapan (STAD) dipadu mind mapping berbasis lesson study untuk meningkatkan motivasi dan pemahaman konsep. JINoP (Jurnal Inovasi Pembelajaran), 4(1), 26-34. https://doi.org/10.22219/jinop.v4i1.4955

Razali, N. M., \& Wah, Y. B. (2011). Power comparisons of Shapiro-Wilk, Kolmogorov-Smirnov, Lilliefors and Anderson-Darling tests. Journal of Statistical Modeling and Analytics, 2(1), 21-33.

Royston, P. (1992). Approximating the ShapiroWilk W-test for non-normality. Statistics and Computing, 2(3), 117-119. https://doi.org/10.1007/BF01891203

Schunk, D. H., Pintrich, P. R., \& Meece, J. L. (2008). Motivation in education: Theory, research, and applications. New Jersey: Pearson/Merrill Prentice Hall.

Shabrina, S., \& Kuswanto, H. (2018). Androidassisted mobile physics learning through Indonesian batik culture: Improving students' creative thinking and problem solving. International Journal of Instruction, 11(4), 287-302. https://doi.org/10.12973/iji.2018.11419a

Sládek, P., Miléř, T., \& Benárová, R. (2011). How to increase students' interest in science and technology. Procedia - Social and Behavioral Sciences, 12, 168-174. https://doi.org/https://doi.org/10.1016/j.sb spro.2011.02.024

Spektor-Levy, O., Baruch, Y. K., \& Mevarech, Z. (2013). Science and scientific curiosity in pre-school-The teacher's point of view. International Journal of Science Education, 35(13), 2226-2253. https://doi.org/10.1080/09500693.2011.63
1608

Stanojevic, D. M., Cenić, D., \& Cenić, S. (2018). Application of computers in modernization of teaching science. International Journal of Cognitive Research in Science, Engineering and Education:(IJCRSEE), 6(2), 89-106. Retrieved from https://dialnet.unirioja.es/servlet/articulo? codigo $=6545551$

Sudarwati, I., Khanafiyah, S., \& Sugiyanto, S. (2017). Online-course development via discussion-forum on the students of Physic Education Universitas Negeri Semarang. Jurnal Pendidikan Fisika Indonesia, 13(1), 9-18. https://doi.org/10.15294/jpfi.v13i1.8982

Sugiyono, S. (2008). Metode penelitian pendidikan: (pendekatan kuantitatif, kualitatif dan $R \& D$ ). Bandung: Alfabeta.

Thiagarajan, S., Semmel, D. S., \& Semmel, M. I. (1974). Instructional development for training teachers of exceptional children: A sourcebook. Blomington: may be ordered from the Council for Exceptional Children.

Widowati, A., Nurohman, S., \& Anjarsari, P. (2017). Developing science learning material with authentic inquiry learning approach to improve problem solving and scientific attitude. Jurnal Pendidikan IPA Indonesia, 6(1).

Wilujeng, I. (2016). Pengintegrasian potensi lokal dalam pembelajaran IPA alternatif peningkatan daya saing global. In Prosiding Seminar Nasional IPA VII (pp. 680-688). Semarang: Universitas Negeri Semarang.

Yulianti, D. (2017). Problem-based learning model used to scientific approach based worksheet for physics to develop senior high school students characters. In Journal of Physics: Conference Series (Vol. 824, p. 12009). IOP Publishing. https://doi.org/10.1088/17426596/824/1/012009 